\title{
Larvicidal Activities against Aedes aegypti of Supernatant and Pellet Fractions from Cultured Bacillus spp. Isolated from Amazonian Microenvironments
}

\author{
Ricardo M. Katak ${ }^{1, *}\left(\mathbb{D}\right.$, Elerson M. Rocha ${ }^{1}$, Juan C. Oliveira ${ }^{1}$, Veranilce A. Muniz ${ }^{2}$, Marta R. Oliveira ${ }^{3}$, \\ Francisco A. S. Ferreira ${ }^{4}$, William R. Silva ${ }^{4}$, Rosemary A. Roque ${ }^{5}$, Antonia Q. L. de Souza ${ }^{6}$, \\ Jayme A. Souza-Neto ${ }^{7}$, , Olle Terenius ${ }^{8}$, Osvaldo Marinotti ${ }^{9, *(\mathbb{C}}$ and Wanderli P. Tadei ${ }^{5}$
}

1 Programa Multi-Institucional de Pós-Graduação em Biotecnologia-PPGBIOTEC, Universidade Federal do Amazonas-UFAM, Manaus 69042-270, Brazil; elerson.matos@hotmail.com (E.M.R.); juabio1807@gmail.com (J.C.O.)

2 Programa de Pós-Graduação em Biotecnologia e Recursos Naturais da Amazônia-PPGMBT, Universidade do Estado do Amazonas-UEA, Manaus 69042-270, Brazil; veralves2@gmail.com

3 Programa de Pós-Graduação em Biodiversidade e Biotecnologia-PPGBIONORTE, Universidade Federal do Amazonas_UFAM, Manaus 69042-270, Brazil; moliveirabiotec@gmail.com

4 Programa de Pós-Graduação em Ciências Biológicas (Entomologia)—PPGENT, Instituto Nacional de Pesquisas da Amazônia-INPA, Manaus 69042-270, Brazil; fcoaugusto.bio@gmail.com (F.A.S.F.); wrds021@gmail.com (W.R.S.)

check for updates

Citation: Katak, R.M.; Rocha, E.M.; Oliveira, J.C.; Muniz, V.A.; Oliveira M.R.; Ferreira, F.A.S.; Silva, W.R.; Roque, R.A.; de Souza, A.Q.L.; Souza-Neto, J.A.; et al. Larvicidal Activities against Aedes aegypti of Supernatant and Pellet Fractions from Cultured Bacillus spp. Isolated from Amazonian Microenvironments. Trop. Med. Infect. Dis. 2021, 6, 104. https:// doi.org/10.3390/tropicalmed6020104

Academic Editor: Kefyalew Addis Alene

Received: 11 May 2021

Accepted: 13 June 2021

Published: 17 June 2021

Publisher's Note: MDPI stays neutral with regard to jurisdictional claims in published maps and institutional affiliations.

Copyright: (๑) 2021 by the authors. Licensee MDPI, Basel, Switzerland. This article is an open access article distributed under the terms and conditions of the Creative Commons Attribution (CC BY) license (https:// creativecommons.org/licenses/by/ $4.0 /)$.
5 Laboratório de Controle Biológico e Biotecnologia da Malária e Dengue-LCBBMD, Instituto Nacional de Pesquisas da Amazônia-INPA, Manaus 69042-270, Brazil; rosebio1996@yahoo.com.br (R.A.R.); wptadei@gmail.com (W.P.T.)

6 Faculdade de Ciências Agrárias-FCA, Universidade Federal do Amazonas-UFAM, Manaus 69042-270, Brazil; antoniaqlsouza@gmail.com

7 School of Agricultural Sciences, Department of Bioprocesses and Biotechnology, Central Multi User Laboratory, São Paulo State University_UNESP, Botucatu 18600-000, Brazil; jayme.souza-neto@unesp.br

8 Department of Cell and Molecular Biology, Microbiology, Uppsala University, 74174 Uppsala, Sweden; olle.terenius@icm.uu.se

9 MTEKPrime, Aliso Viejo, CA 92656, USA

* Correspondence: ricardokatak@hotmail.com (R.M.K.); omarinotti@gmail.com (O.M.)

Abstract: The Aedes aegypti mosquito is the primary vector of Dengue, Chikungunya and Zika causing major problems for public health, which requires new strategies for its control, like the use of entomopathogenic microorganisms. In this study, bacteria from various Amazonian environments were isolated and tested for their pathogenicity to $A$. aegypti larvae. Following thermal shock to select sporulated Bacillus spp., 77 bacterial strains were isolated. Molecular identification per 16S RNA sequences revealed that the assembled strains contained several species of the genus Bacillus and one species each of Brevibacillus, Klebsiella, Serratia, Achromobacter and Brevundimonas. Among the isolated Bacillus sp. strains, 19 showed larvicidal activity against A. aegypti. Two strains of Brevibacillus halotolerans also displayed larvicidal activity. For the first time, larvicidal activity against A. aegypti was identified for a strain of Brevibacillus halotolerans. Supernatant and pellet fractions of bacterial cultures were tested separately for larvicidal activities. Eight strains contained isolated fractions resulting in at least $50 \%$ mortality when tested at a concentration of $5 \mathrm{mg} / \mathrm{mL}$. Further studies are needed to characterize the active larvicidal metabolites produced by these microorganisms and define their mechanisms of action.

Keywords: Amazonian microbiota; bioprospecting; biological control; Bacillus; mosquito

\section{Introduction}

Vector-borne diseases exert a huge burden of morbidity and mortality worldwide, particularly affecting the poor living in the tropics and subtropics. Aedes (Stegomyia) aegypti (L.) is considered the primary vector of arboviruses causing dengue, Zika and chikungunya 
illnesses [1-3]. The adaptability of these mosquitoes to urban areas, their highly anthropophilic behavior and recent outbreaks of the diseases mentioned above, make this vector an important public health problem to be solved [4-6]. Across the globe, dengue, Zika, and chikungunya outbreaks vary in geographic location, magnitude and duration. Between 95 and 114 million dengue infections are estimated to occur globally per year, with 32 to 66 million febrile disease cases, and 4 million infections that require hospitalization [7]. In 2015, a Zika outbreak in Brazil accounted for 440 thousand to 1.3 million infection cases, quickly spreading throughout Latin America and the Caribbean [8]. Zika was declared a public health emergency of international concern by the World Health Organization in February 2016 [9]. In the early 2000s, chikungunya outbreaks were reported in countries in Africa, Asia, and Europe. In 2013, it emerged in the Americas where within the first year, over a million new cases were reported [10].

The lack of preventive drugs for dengue, Zika and chikungunya, makes the mosquito vector the main target for the comprehensive control of these diseases [11]. Currently, the focus is on reducing the source of these mosquitoes, using mainly insecticides. However, the increased resistance of mosquitoes to chemical insecticides makes them nonfunctional in many environments $[12,13]$. New tools and approaches are needed to control the populations of $A$. aegypti.

Entomopathogenic microorganisms are promising tools for the control of diseasecarrying mosquitoes [14-18]. Bacteria of the genus Bacillus, mainly Bacillus thuringiensis israelensis (Bti) and Lysinibacillus sphaericus (Syn. Bacillus sphaericus, Bs), have been used worldwide and for decades as biological products for the control of mosquitoes by killing their larvae [19-21]. Despite products based on Bti and Bs being powerful and selective insecticides, alternative Bacillus sp. strains should be sought as alternatives, potentially revealing new insecticide toxins.

Besides Bti and Bs, microorganisms such as the bacteria Chromobacterium sp. Panama [22], Xenorhabdus and Photorhabdus [23] and the fungi Beauveria bassiana and Metarhizium anisopliae among others, have demonstrated mosquitocidal activities [24]. The present challenge is to convert these promising observations into products that are ready to be incorporated into mosquito control interventions.

The Amazon tropical rainforest contains $\sim 25 \%$ of the world's terrestrial biodiversity [25], including insects, mammals, birds, and microorganisms. Here, we describe the isolation and characterization of bacteria from diverse Amazonian environments and their potential as new components of $A$. aegypti control programs. We identified bacterial strains that exhibit larvicidal activity similar to commercial Bti. Further studies are needed for the characterization of their active compounds. Metabolites derived from the isolated bacteria may be molecules with novel insecticidal properties that can be developed as biological tools to improve the control of mosquito-transmitted diseases.

\section{Materials and Methods}

\subsection{Sample Collection and Bacteria Isolation}

Water and soil samples were collected in the municipalities of Coari, Manaus and Parintins, Amazonas State, Brazil (Table 1, Figure 1). All the biological material collected and analyzed during the present study was collected with official permission (21263-1) given by 'Sistema de Autorização e Informação em Biodiversidade' (SISBIO) of the Brazilian Ministry of Environment (MMA).

Soil samples $(10 \mathrm{~g})$ were taken from the field with a $10 \mathrm{~cm}$ long by $5 \mathrm{~cm}$ diameter cylindrical tube. Surface water samples $(10 \mathrm{~mL})$ were collected in $50 \mathrm{~mL}$ sterile Falcon tubes. Three soil samples and/or three water samples, approximately $5 \mathrm{~m}$ apart from each other were collected from each site. All water and soil samples were stored on ice, transported to the Malaria and Dengue Laboratory (Instituto Nacional de Pesquisas da Amazônia-INPA) and processed within $24 \mathrm{~h}$. 
Table 1. Geographic location, date and characteristics of the 15 sites where water and soil were collected.

\begin{tabular}{ccccccc}
\hline Municipality & & Collection Site & GPS Coordinates & Description & Sample Type & Date \\
\hline Coari & 1 & Sítio do Gordo & $4^{\circ} 06^{\prime} 45.5^{\prime \prime} \mathrm{S} 63^{\circ} 07^{\prime} 44.0^{\prime \prime} \mathrm{W}$ & artificial lake & water & $02 / 2017$ \\
\hline & 2 & Ramal do 7 (Brasileirinho) & $3^{\circ} 01^{\prime} 42.2^{\prime \prime} \mathrm{S} 59^{\circ} 52^{\prime} 15.6^{\prime \prime} \mathrm{W}$ & primary forest & soil & $03 / 2017$ \\
& 3 & Campus-UFAM & $3^{\circ} 05^{\prime} 48.8^{\prime \prime} \mathrm{S} 59^{\circ} 58^{\prime} 23.6^{\prime \prime} \mathrm{W}$ & residual forest & soil & $04 / 2017$ \\
& 4 & Bosque da Ciência-INPA & $3^{\circ} 06^{\prime} 01.3^{\prime \prime} \mathrm{S} 59^{\circ} 59^{\prime} 06.6^{\prime \prime} \mathrm{W}$ & residual forest & soil & $02 / 2017$ \\
Manaus & 5 & Casa 15-INPA & $3^{\circ} 05^{\prime} 47.2^{\prime \prime} \mathrm{S} 59^{\circ} 59^{\prime} 09.5^{\prime \prime} \mathrm{W}$ & residual forest & soil & $05 / 2017$ \\
& 6 & Sitio Portela 1 & $3^{\circ} 02^{\prime} 47.0^{\prime \prime} \mathrm{S} 59^{\circ} 52^{\prime} 54.4^{\prime \prime} \mathrm{W}$ & fish tank & water & $02 / 2017$ \\
& 7 & Sitio Dona Chagas & $3^{\circ} 02^{\prime} 33.5^{\prime \prime} \mathrm{S} 59^{\circ} 53^{\prime} 15.6^{\prime \prime} \mathrm{W}$ & fish tank & water & $06 / 2017$ \\
& 8 & Sítio Portela 2 & $3^{\circ} 02^{\prime} 47.5^{\prime \prime} \mathrm{S} 59^{\circ} 52^{\prime} 56.8^{\prime \prime} \mathrm{W}$ & fish tank & water & $02 / 2017$ \\
\hline & 9 & Parananema & $2^{\circ} 40^{\prime} 30.9^{\prime \prime} \mathrm{S} 56^{\circ} 45^{\prime} 59.2^{\prime \prime} \mathrm{W}$ & primary forest & soil & $03 / 2017$ \\
& 10 & Aninga & $2^{\circ} 39^{\prime} 07.6^{\prime \prime} \mathrm{S} 56^{\circ} 46^{\prime} 50.3^{\prime \prime} \mathrm{W}$ & natural pond & water & $03 / 2017$ \\
& 11 & Lagoa Francesa & $2^{\circ} 37^{\prime} 34.7^{\prime \prime} \mathrm{S} 56^{\circ} 43^{\prime} 37.3^{\prime \prime} \mathrm{W}$ & natural pond & water & $04 / 2017$ \\
& 12 & Arreial & $2^{\circ} 39^{\prime} 39.2^{\prime \prime} \mathrm{S} 56^{\circ} 46^{\prime} 07.6^{\prime \prime} \mathrm{W}$ & creek & water & $03 / 2017$ \\
& 13 & Macurany & $2^{\circ} 40^{\prime} 33.6^{\prime \prime} \mathrm{S} 56^{\circ} 45^{\prime} 30.2^{\prime \prime} \mathrm{W}$ & primary forest & soil & $04 / 2017$ \\
& 14 & Parananema & $2^{\circ} 40^{\prime} 30.9^{\prime \prime} \mathrm{S} 56^{\circ} 45^{\prime} 59.2^{\prime \prime} \mathrm{W}$ & creek & water & $02 / 2017$ \\
& 15 & Macurany (Sítio Fanuel) & $2^{\circ} 39^{\prime} 06.7^{\prime \prime} \mathrm{S} 56^{\circ} 43^{\prime} 29.0^{\prime \prime} \mathrm{W}$ & natural pond & water & $04 / 2017$ \\
\hline
\end{tabular}

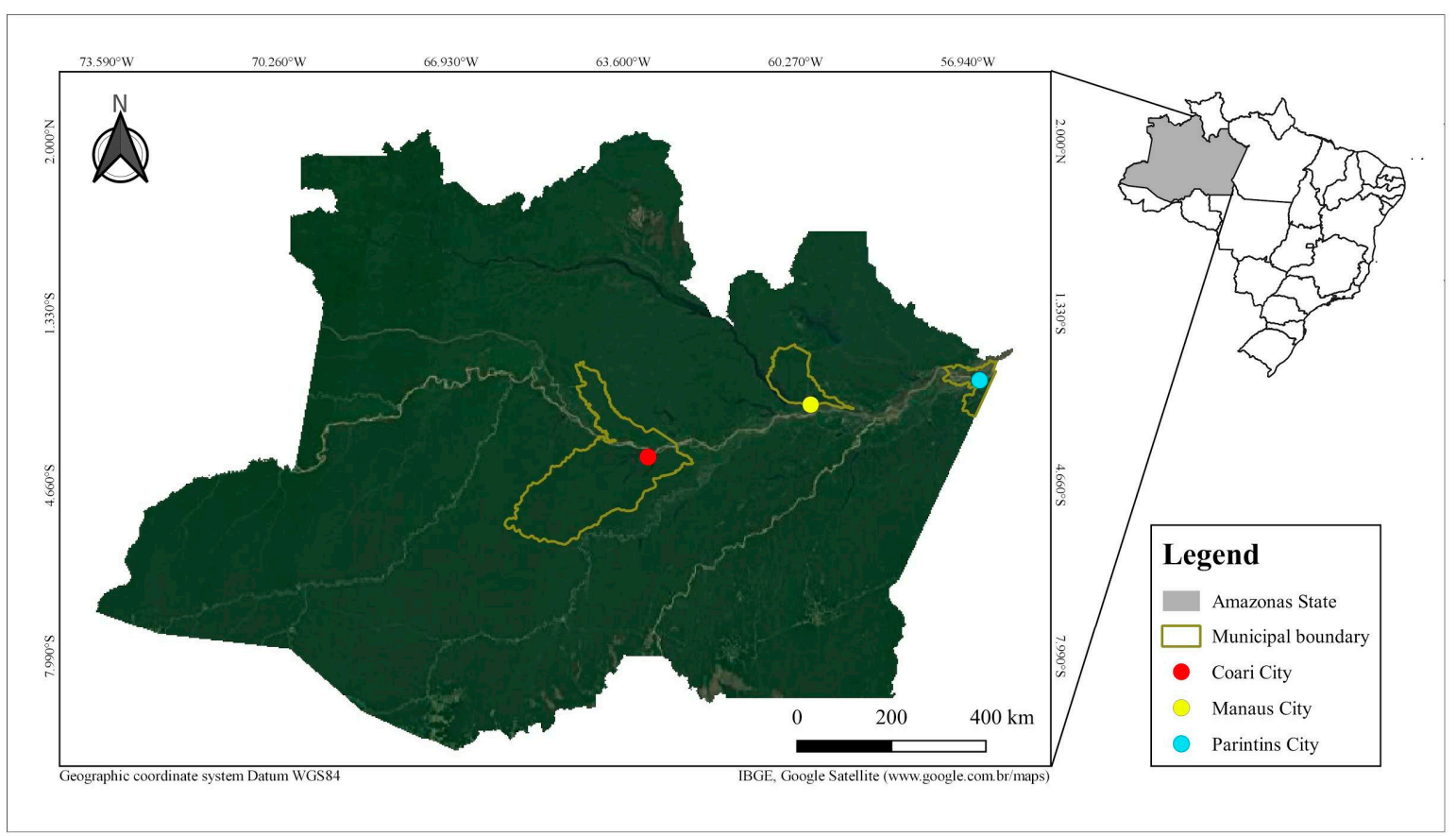

Figure 1. Sample collection locations. GPS coordinates, dates of collections and descriptions of collection sites are available in Table 1.

Soil samples $(1 \mathrm{~g})$ were suspended in $10 \mathrm{~mL}$ sterile water and vortexed for $10 \mathrm{~min}$. Three 10-fold serial dilutions were prepared by diluting the vortexed material with sterile water. Water samples were used without any dilution. Soil and water samples were incubated at $80^{\circ} \mathrm{C}$ for $12 \mathrm{~min}$, for selection of sporulated Bacillus spp. [26,27]. Then, $50 \mu \mathrm{L}$ aliquots were spread on Petri dishes containing nutrient agar (NA), Luria-Bertani agar (LB), or the ISP2 medium. Fluconazole $(20 \mathrm{mg} / \mathrm{mL})$ was added to the media to prevent fungal growth. All Petri dishes were incubated at $30{ }^{\circ} \mathrm{C}$ for 24 or $48 \mathrm{~h}$. Negative control plates with only sterile water resulted in no colonies. The streak plate technique was applied for isolating specific bacteria from the original colonies potentially containing a mixture of microorganisms. 


\subsection{Morphological and Molecular Characterization}

Colony morphology was inspected for size, shape, texture, elevation, color and Gram staining using standard microbiological techniques and a 100x magnification microscope. DNA was extracted from each colony for $16 \mathrm{~S}$ rRNA gene amplification and sequencing as follows. DNA extraction, from isolated bacterial colonies, was performed with InstaGene ${ }^{\mathrm{TM}}$ Matrix (BioRad-Hercules, Califórnia, EUA) following the manufacturer's instructions. DNA was spectrophotometrically quantified and adjusted to $150 \mathrm{ng} / \mu \mathrm{L}$. Bacterial $16 \mathrm{~S}$ rRNA genes were amplified by PCR using Taq Pol-Master Mix 2X (Cellco Biotec-Jardim Bandeirantes, São Carlos-SP, Brazil), and the primers 27F (5'-AGAGTTTGATCMTGGCTC AG-3') [28] and 1100R (5'-AGGGTTGCGCTCGTT-3') modified from [29] used in a previous study [30]. Each reaction consisted of $12.5 \mu \mathrm{L}$ Master Mix; $1 \mu \mathrm{L}$ DNA (150 ng/ $\mu \mathrm{L}) ; 10.5 \mu \mathrm{L}$ $\mathrm{H}_{2} \mathrm{O}$ milli-Q and $0.5 \mu \mathrm{L}(10 \mathrm{pMol})$ of each primer. The PCR program had an initial denaturation at $95{ }^{\circ} \mathrm{C}$ for $3 \mathrm{~min}$, followed by 35 cycles of $\left(94{ }^{\circ} \mathrm{C}\right.$ for $1 \mathrm{~min}, 54{ }^{\circ} \mathrm{C}$ for $40 \mathrm{~s}$, $72{ }^{\circ} \mathrm{C}$ for $90 \mathrm{~s}$ ), followed by a final extension at $72{ }^{\circ} \mathrm{C}$ for $5 \mathrm{~min}$. Amplicon production and size were verified by electrophoresis in a $0.8 \%$ agarose gel, stained with ethidium bromide. Amplicons were purified with PCR Purification Kit (Cellco Biotec-Jardim Bandeirantes, São Carlos-SP, Brazil), following the manufacturer's instructions and 200 ng of purified DNA was used for each sequencing reaction (BigDye Terminator V 3.1, Life TechnologiesCarlsbad, Califórnia, EUA and $10 \mathrm{pMol}$ of primer). The 27F and 1100R primers were used in separate sequencing reactions, generating data from both DNA strands.

All 16S rRNA gene sequences were assembled at http:/ / asparagin.cenargen.embrapa. $\mathrm{br} / \mathrm{phph} /$ (accessed 30 May 2019) using the CAP3 program with the capability to clip $5^{\prime}$ and $3^{\prime}$ low-quality regions of reads, apply quality values in overlaps between reads, and generate consensus sequences [31]. Consensus sequences were compared with $16 \mathrm{~S}$ sequences in GenBank applying BLASTn (https:/ /blast.ncbi.nlm.nih.gov/Blast.cgi, accessed 30 May 2019) at the National Center for Biotechnology Information (NCBI) and Ribossomal Database Project (RDP-II http://rdp.cme.msu.edu/comparison/comp.jsp, accessed 30 May 2019). All sequences were registered in the SisGen database (Sistema Nacional de Gestão do Patrimônio Genético e do Conhecimento Tradicional Associado, A9C8D56) and are available in GenBank with accession numbers MT052595-MT052669 and MT163315-MT163316.

\subsection{Fractionation of Bacterial Cultures}

Each bacterial strain was inoculated in $2 \mathrm{~mL}$ of the culture medium from which it was isolated (Table S1) and this starting culture was kept in a shaker incubator at $30{ }^{\circ} \mathrm{C}$ and $180 \mathrm{rpm}$ for $24 \mathrm{~h}$. Fifty $\mu \mathrm{L}$ of the initial culture was transferred to $500 \mathrm{~mL}$ of medium followed by incubation at $30^{\circ} \mathrm{C}$ and $180 \mathrm{rpm}$ for $120 \mathrm{~h}$. After $120 \mathrm{~h}$ incubation, each culture was centrifuged at $4{ }^{\circ} \mathrm{C}$ and $2800 \times g$ for $40 \mathrm{~min}$. The supernatant was treated as described by [18], with modifications. Following centrifugation, the supernatant was filtered through a $0.22 \mu \mathrm{M}$ Millipore membrane and lyophilized (Terroni-Jardim Jockei Club A, São Carlos-SP) for $72 \mathrm{~h}, 150 \mathrm{mmHg}$. An aliquot of the supernatant was plated on agarmedium to certify the absence of viable cells, after centrifugation, the pellet was divided in two identical parts. One of them was stored frozen at $-20^{\circ} \mathrm{C}$. The second portion was autoclaved at $127^{\circ} \mathrm{C}$ for $30 \mathrm{~min}$ and then frozen at $-20^{\circ} \mathrm{C}$. Both pellet fractions were then lyophilized as described above.

\subsection{Mosquito Rearing}

The A. aegypti MAO strain was maintained at $26 \pm 2{ }^{\circ} \mathrm{C}, 80 \%$ relative humidity and $12 \mathrm{~L}: 12 \mathrm{D}$ light cycle. Larvae were fed Tetramin fish food. Adults (males and females kept together) were given access to $10 \%$ sucrose solution ad libitum and were blood-fed on Hamster Mesocricetus auratus (W). All experiments were conducted in accordance with relevant regulations following the guidelines of the "Conselho Nacional de Controle de Experimentação Animal" —CONCEA and was approved by the "Comissao de Ética no 
Uso de Animais" - CEUA (053/2018-SEI 01280.001770/2018-71) of the "Instituto Nacional de Pesquisas da Amazônia"-INPA, at a meeting on 29 October 2018.

\subsection{Screening for Larvicidal Activity}

Bioassays were performed according to WHO guidelines [32], as described by Soaresda-Silva et al. [33]. Each bacterial strain was inoculated in $150 \mathrm{~mL}$ of the same culture medium from which it was isolated (Table S1) and incubated at $30^{\circ} \mathrm{C}$ and $180 \mathrm{rpm}$ for $120 \mathrm{~h}$ to achieve an optical density of 8 units in the McFarland scale $\left(\sim 24 \times 10^{8}\right.$ cells $\left./ \mathrm{mL}\right)$. Larval mortality due to exposure to bacterial culture was assessed on three consecutive days. Each day, five cups were prepared for each tested strain, each cup containing 10 third instar A. aegypti larvae, $9 \mathrm{~mL}$ of distilled water, food (Tetramin), and $1 \mathrm{~mL}$ of bacteria culture (bacteria plus medium). Dead larvae were counted in each cup at 24,48 and $72 \mathrm{~h}$ after exposure. No mortality was observed at any time in negative controls without bacteria. Bacillus thuringiensis israelensis Bti-BR101 was used as positive control to validate our protocol and to comparatively assess larvicidal activity.

\subsection{Bioassays with Fractionated Metabolites}

Larvicidal activities of lyophilized supernatants and pellets were evaluated separately. Initially, the lyophilized products were prepared as follows; (i) SUP $=50 \mathrm{mg}$ of supernatant $+10 \mathrm{~mL}$ of water; (ii) PEL $=50 \mathrm{mg}$ of pellet $+10 \mathrm{~mL}$ of water; (iii) APEL $=50 \mathrm{mg}$ of autoclaved pellet $+10 \mathrm{~mL}$ of water e; (iv) APEL $+\mathrm{SUP}=25 \mathrm{mg}$ of autoclaved pellet $+25 \mathrm{mg}$ of supernatant $+10 \mathrm{~mL}$ of water. All the samples were homogenized with a vortex for $40 \mathrm{~min}$. A. aegypti larval mortality was assessed as described above at 24,48 and $72 \mathrm{~h}$.

\subsection{Determination of Lethal Concentrations $\left(L C_{50}\right)$ and $\left(L C_{90}\right)$}

Strains eliciting at least $50 \%$ larval mortality in previous assays were further analyzed by standardized WHO protocols [32] and lethal concentrations $\left(\mathrm{LC}_{50}\right.$ and $\left.\mathrm{LC}_{90}\right)$ were determined separately for SUP, PEL, APEL and APEL+SUP fractions. These assays were conducted in five replicates, each containing $150 \mathrm{~mL}$ of water, 20 third instar larvae and $0.04,0.03,0.02,0.01,0.008,0.005,0.001,0.0008$ or $0.0003 \mathrm{mg} / \mathrm{L}$ of fractionated cultures. Dead larvae were counted at 24,48 and $72 \mathrm{~h}$ after exposure. Negative and positive controls were included as described above using Bti BR101 as active strain. Data from concentrations causing between $10 \%$ and about $95 \%$ mortality of mosquito larvae were used for statistical analyses.

$\mathrm{LC}_{50}$ and $\mathrm{LC}_{90}$ were assessed by Probit, with $p \leq 0.05$ [34], using the statistical software Polo Plus 1.0 (LeOra Software, Berkeley, CA, USA) [35]. Lethal concentrations and confidence interval (CI 95\%) were analyzed by the Lilliefors normality test (K samples), analysis of variance (ANOVA), multiple comparison Tukey test $(p \leq 0.05)$ and Student's t test with the software BioEstat 5.3 for Windows [36].

\section{Results}

\subsection{Bacteria Strain Isolation and Characterization}

Seventy-seven bacterial strains were isolated from soil and water samples from 15 different geographical locations (Table S1). Among them, 38 originated from soil and 39 from water samples. Amplification and sequencing of $16 \mathrm{~S}$ rRNA genes, and comparison of the sequences with the NCBI database, revealed that the assembled collection contains representatives of six genera: Bacillus, Brevibacillus, Achromobacter, Serratia, Klebsiella and Brevundimonas. Among them are representatives of the genus Bacillus and one species of each Brevibacillus, Achromobacter, Serratia, Klebsiella and Brevundimonas (Table S1). Species assignment of every queried sequence would be the desired outcome, but in many cases the limited resolution of the 16S rRNA locus precluded an accurate classification at the species level. Taxonomic classification at the genus level was then assigned to the isolated strains. 


\subsection{Larvicidal Activity of Isolated Bacterial Strains}

Exposure of A. aegypti larvae to cultured bacteria from all isolated strains $\left(\sim 24 \times 10^{8}\right.$ cells $/ \mathrm{mL}$ ) revealed that 21 resulted in a mortality equal to or greater than $50 \%$ within $72 \mathrm{~h}$ and these were further studied (Table 2). Twenty of them are from the genus Bacillus. One Brevibacillus halotolerans strain, $\mathrm{SPa} 07$, isolated from the soil killed $100 \%$ of the A. aegypti larvae in $48 \mathrm{~h}$. Eleven of the Bacillus strains killed $100 \%$ of the larvae within $24 \mathrm{~h}$, as did the positive control strain Bti BR101.

Table 2. Isolated strains with larvicidal activity against $A$. aegypti larvae.

\begin{tabular}{cccccc}
\hline \multirow{2}{*}{ Strain } & Isolated from & GenBank acc. N ${ }^{\circ}$; Species & \multicolumn{3}{c}{ Cumulative Mortality } \\
& & $\mathbf{2 4} \mathbf{h}$ & $\mathbf{4 8 ~ h}$ & $\mathbf{7 2} \mathbf{~ h}$ \\
\hline BR101 & Positive control & Bacillus thuringiensis var.israelensis & $100 \%$ & - & - \\
Spa09 & Soil & MT052636; Bacillus sp. & $100 \%$ & - & - \\
SBC13 & Soil & MT052634; Bacillus sp. & $100 \%$ & - & - \\
SP06 & Soil & MT052669; Bacillus sp. & $100 \%$ & - & - \\
SPO2 & Water & MT052609; Bacillus safensis & $100 \%$ & - & - \\
SPO5 & Water & MT052624; Bacillus sp. & $100 \%$ & & \\
SX02 & Water & MT052611; Bacillus sp. & $100 \%$ & & - \\
APR6I & Water & MT052596; Bacillus sp. & $100 \%$ & - & - \\
APR10I & Water & MT052598; Bacillus sp. & $100 \%$ & - & - \\
GD02.13 & Water & MT163315; Bacillus sp. & $100 \%$ & - & - \\
SX06 & Water & MT052643; Bacillus megaterium & $100 \%$ & & \\
SX08 & Water & MT052649; Bacillus velezensis & $100 \%$ & & \\
Spa07 & Soil & MT052647; Brevibacillus halotolerans & $60 \%$ & $100 \%$ & - \\
Spa03 & Soil & MT052618; Bacillus sp. & $90 \%$ & $97 \%$ & $100 \%$ \\
LFP2 & Water & MT052629; Bacillus subtilis & $10 \%$ & $80 \%$ & $90 \%$ \\
Spa22 & Soil & MT052639; Bacillus safensis & $47 \%$ & $80 \%$ & $83 \%$ \\
Spa04 & Soil & MT052633;Brevibacillus halotolerans & $70 \%$ & $70 \%$ & $80 \%$ \\
SMP1.2 & Soil & MT052614; Bacillus sp. & $56 \%$ & $63 \%$ & $67 \%$ \\
SBC2 & Soil & MT052620; Bacillus subtilis & $27 \%$ & $57 \%$ & $67 \%$ \\
SBC1 & Soil & MT052667; Bacillus sp. & $33 \%$ & $53 \%$ & $63 \%$ \\
Spa14 & Soil & MT052651; Bacillus sp. & $37 \%$ & $57 \%$ & $57 \%$ \\
SX15 & Water & MT163316; Bacillus safensis & - & $67 \%$ & $67 \%$ \\
\hline
\end{tabular}

Mortality was assessed at 24, 48 and $72 \mathrm{~h}$ after exposure to bacterial cultures diluted 10-fold in water. No mortality was observed in negative controls without bacteria and the strain BR101 was used as positive control, inducing $100 \%$ mortality within $24 \mathrm{~h}$. Values are the average of three biological replicates, each challenging 10 third instar larvae in $9 \mathrm{~mL}$ of distilled water and $1 \mathrm{~mL}\left(\sim 24 \times 10^{8}\right.$ cells $\left./ \mathrm{mL}\right)$ of bacterial culture (bacteria plus medium).

\subsection{Larvicidal Activity of Fractionated Bacterial Cultures}

All the 21 strains identified above were tested in another series of assays to identify larvicidal activities in cellular and secreted components separately. Bacterial cultures were submitted to centrifugation generating pellets containing bacteria and supernatant (SUP = medium/secreted molecules). Furthermore, the larvicidal activity of autoclaved pellets (APEL = unviable bacteria) was compared with the activity of untreated pellets (PEL = viable bacteria). The bacterial biomass and supernatant fractions were lyophilized before evaluating their biological activity of mosquito larvicide and determining lethal concentrations of the larvicide for $50 \%$ and $90 \%$ mortality, $\mathrm{LC}_{50}$ and $\mathrm{LC}_{90}$.

Eight out of the 21 tested strains contained one or more fractions resulting in at least $50 \%$ mortality when assayed at a concentration of $5 \mathrm{mg} / \mathrm{mL}$ (Figure 2). Larvicidal activity was observed mainly in the PEL fractions of the isolated bacteria. The PEL fractions of five strains killed $100 \%$ of the larvae in less than $24 \mathrm{~h}$, as did the PEL fraction of BtiBR101 (Figure 2B). LCs determined for these five newly isolated strains were statistically indistinguishable from LCs determined for BtiBR101 (i.e., 72 h LC 90 0.012-0.018 mg/mL, detailed values and statistical analysis available in Table 3 and Table S2B). Autoclaved pellets lost their larvicidal activity, except for B. safensis SPa22, which killed 100\% of A. aegypti larvae in $72 \mathrm{~h}$ (Figure 2C). APEL from SPa22 demonstrated a delayed activity with $\mathrm{LC}_{50}$ and $\mathrm{LC}_{90}$ ten-fold lower than the autoclaved pellet from the control strain BtiBR101. 
A

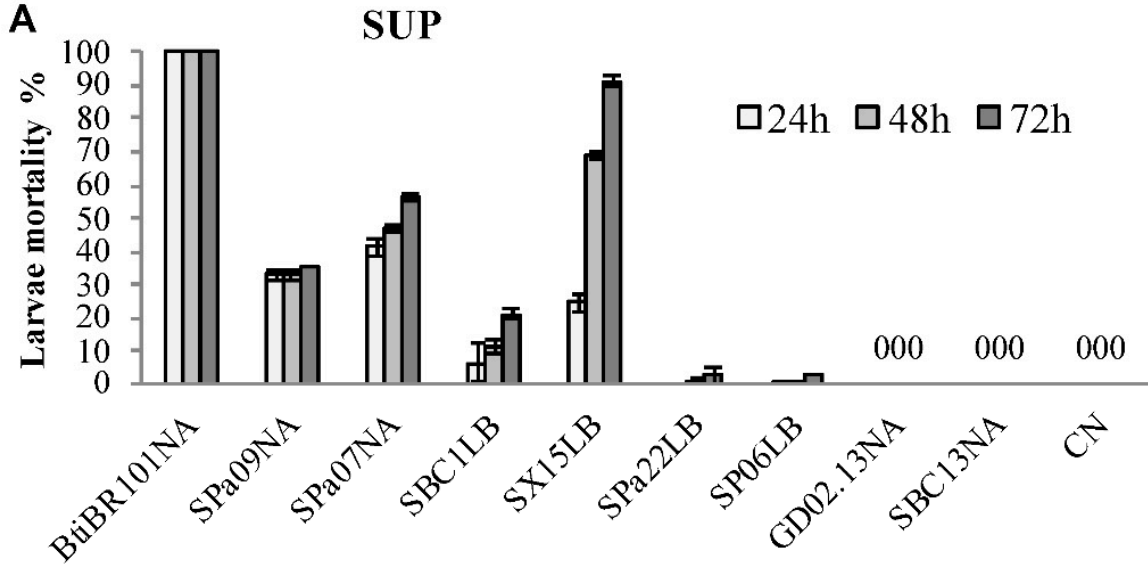

C

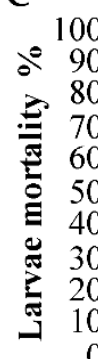

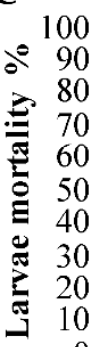

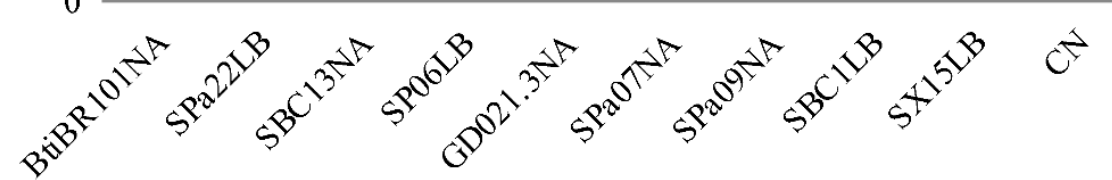

B

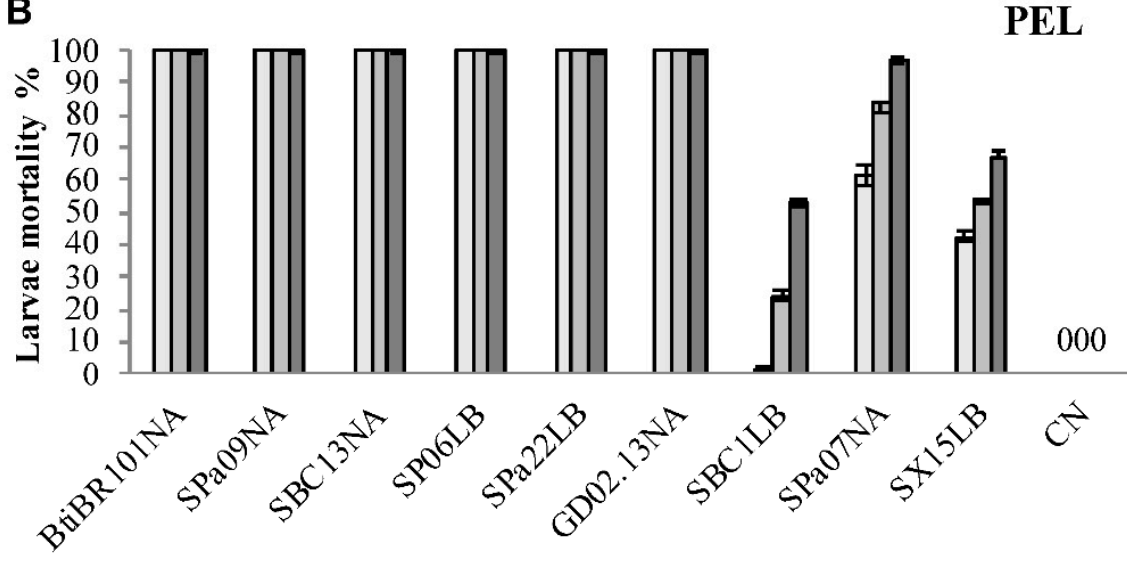

APEL+SUP

D

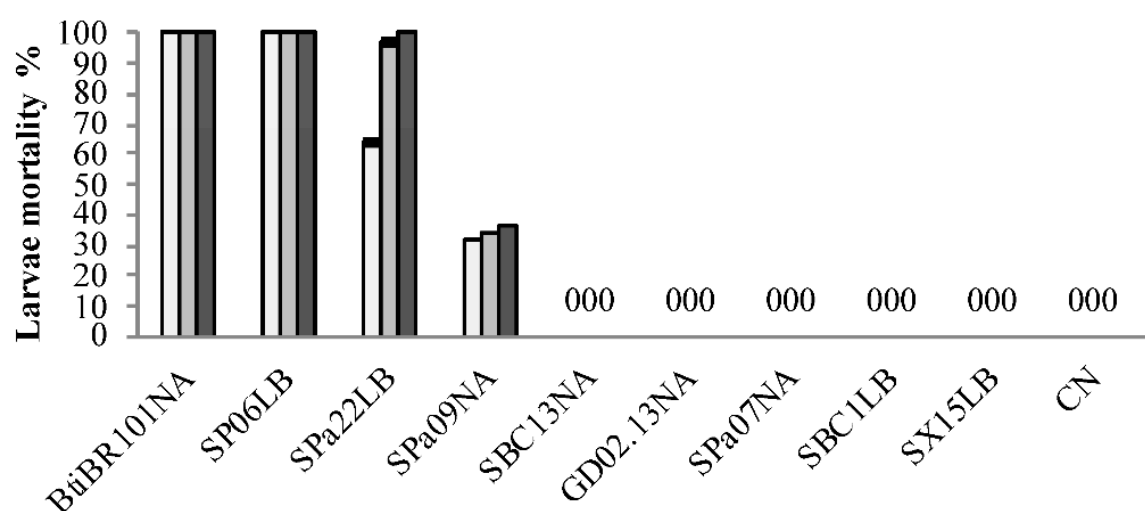

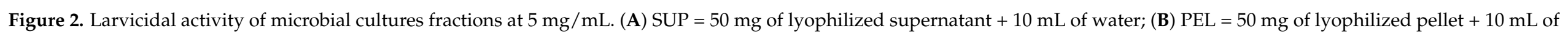

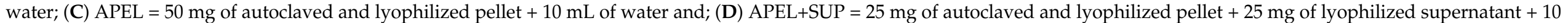

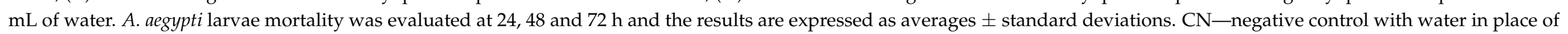
microbial culture fractions. 
Table 3. $\mathrm{LC}_{50}$ and $\mathrm{LC}_{90}$ values of microbial culture fractions against $A$. aegypti larvae.

\begin{tabular}{|c|c|c|c|c|c|c|c|c|c|c|c|c|c|}
\hline \multirow[t]{3}{*}{ Strain } & \multicolumn{6}{|c|}{ PEL } & \multirow[t]{3}{*}{ Strain } & \multicolumn{6}{|c|}{ APEL } \\
\hline & \multicolumn{2}{|c|}{$24 \mathrm{~h}$} & \multicolumn{2}{|c|}{$48 \mathrm{~h}$} & \multicolumn{2}{|c|}{$72 \mathrm{~h}$} & & \multicolumn{2}{|c|}{$24 \mathrm{~h}$} & \multicolumn{2}{|c|}{$48 \mathrm{~h}$} & \multicolumn{2}{|c|}{$72 \mathrm{~h}$} \\
\hline & $\mathrm{CL}_{50}$ & $\mathrm{CL}_{90}$ & $\mathrm{CL}_{50}$ & CL90 & $\mathrm{CL}_{50}$ & $\mathrm{CL}_{90}$ & & $\mathrm{CL}_{50}$ & $\mathrm{CL}_{90}$ & $\mathrm{CL}_{50}$ & $\mathrm{CL}_{90}$ & $\mathrm{CL}_{50}$ & $\mathrm{CL}_{90}$ \\
\hline Bti & $(0.008) \mathrm{bc}$ & $(0.058) \mathrm{a}$ & $(0.008) a$ & $(0.023) \mathrm{a}$ & $(0.003) \mathrm{a}$ & $(0.012) \mathrm{a}$ & Bti & - & - & - & - & - & - \\
\hline SPa22 & $(0.013) \mathrm{ab}$ & $(0.113) \mathrm{a}$ & $(0.004) \mathrm{ab}$ & $(0.023) \mathrm{a}$ & $(0.005) \mathrm{a}$ & $(0.015) \mathrm{a}$ & $\mathrm{SPa} 22$ & (0.009)a & $(0.073) \mathrm{a}$ & $(0.006) \mathrm{a}$ & $(0.025) \mathrm{a}$ & $(0.007) \mathrm{a}$ & $(0.018) a$ \\
\hline GD02.13 & $(0.006) \mathrm{c}$ & $(0.148) \mathrm{a}$ & $(0.005) \mathrm{ab}$ & $(0.017) \mathrm{a}$ & $(0.003) \mathrm{a}$ & $(0.012) \mathrm{a}$ & GD02.13 & - & - & - & - & - & - \\
\hline SP06 & $(0.009) \mathrm{bc}$ & $(0.083) \mathrm{a}$ & (0.007)ab & (0.029)a & (0.007)a & $(0.018) a$ & SP06 & - & - & - & - & - & - \\
\hline SBC13 & $(0.007) \mathrm{c}$ & (0.009)a & $(0.004) \mathrm{b}$ & $(0.019) \mathrm{a}$ & (0.005)a & $(0.012) \mathrm{a}$ & SBC13 & - & - & - & - & - & - \\
\hline SX15 & $(0.010) \mathrm{bc}$ & $(0.088) \mathrm{a}$ & $(0.005) \mathrm{ab}$ & $(0.022) \mathrm{a}$ & - & - & SX15 & - & - & - & - & - & - \\
\hline $\mathrm{BC} 1$ & - & - & - & - & $(0.023) \mathrm{a}$ & $(0.256) \mathrm{a}$ & $\mathrm{BC} 1$ & - & - & - & - & - & - \\
\hline \multirow[t]{2}{*}{ Strain } & \multicolumn{6}{|c|}{ SUP } & Strain & \multicolumn{6}{|c|}{ APEL+SUP } \\
\hline & \multicolumn{2}{|c|}{$24 \mathrm{~h}$} & \multicolumn{2}{|c|}{$48 \mathrm{~h}$} & \multicolumn{2}{|c|}{$72 \mathrm{~h}$} & & \multicolumn{2}{|c|}{$24 \mathrm{~h}$} & \multicolumn{2}{|c|}{$48 \mathrm{~h}$} & \multicolumn{2}{|c|}{$72 \mathrm{~h}$} \\
\hline Bti & $\begin{array}{c}\mathrm{CL}_{50} \\
(0.009) \mathrm{a}\end{array}$ & $\begin{array}{c}\mathrm{CL}_{90} \\
(0.048) \mathrm{a}\end{array}$ & $\begin{array}{c}\mathrm{CL}_{50} \\
(0.008) \mathrm{a}\end{array}$ & $\begin{array}{c}\mathrm{CL}_{90} \\
(0.029) \mathrm{a}\end{array}$ & $\begin{array}{c}\mathrm{CL}_{50} \\
(0.004) \mathrm{a}\end{array}$ & $\begin{array}{c}\mathrm{CL}_{90} \\
(0.004) \mathrm{a}\end{array}$ & Bti & $\begin{array}{c}\mathrm{CL}_{50} \\
(0.005) \mathrm{a}\end{array}$ & $\begin{array}{c}\mathrm{CL}_{90} \\
(0.037) \mathrm{a}\end{array}$ & $\begin{array}{c}\mathrm{CL}_{50} \\
(0.005) \mathrm{a}\end{array}$ & $\begin{array}{c}\mathrm{CL}_{90} \\
(0.018) \mathrm{a}\end{array}$ & $\begin{array}{c}\mathrm{CL}_{50} \\
(0.004) \mathrm{a}\end{array}$ & $\begin{array}{c}\mathrm{CL}_{90} \\
(0.011) \mathrm{a}\end{array}$ \\
\hline SPa09 & - & - & - & - & - & - & SPa09 & - & - & - & - & - & - \\
\hline $\mathrm{SPa} 22$ & - & - & - & - & - & - & SPa22 & (0.007)a & $(0.031) \mathrm{a}$ & (0.007)a & $(0.018) \mathrm{a}$ & $(0.003) \mathrm{a}$ & $(0.012) \mathrm{a}$ \\
\hline SP06 & - & - & - & - & - & - & SP06 & $(0.008) \mathrm{a}$ & $(0.046) \mathrm{a}$ & $(0.006) \mathrm{a}$ & $(0.023) \mathrm{a}$ & (0.003)a & (0.016)a \\
\hline SBC13 & - & - & - & - & - & - & SBC13 & - & - & - & - & - & - \\
\hline $\mathrm{SPa} 07$ & $(0.007) \mathrm{a}$ & $(0.056) \mathrm{a}$ & $(0.006) \mathrm{a}$ & $(0.020) \mathrm{a}$ & $(0.004) \mathrm{a}$ & $(0.004) \mathrm{a}$ & $\mathrm{SPa} 07$ & - & - & - & - & - & - \\
\hline SX15 & (0.006)a & $(0.068) \mathrm{a}$ & $(0.006) \mathrm{a}$ & $(0.068) \mathrm{a}$ & (0.005)a & $(0.005) \mathrm{a}$ & SX15 & - & - & - & - & - & - \\
\hline BC1 & - & - & - & - & - & - & $\mathrm{BC} 1$ & - & - & - & - & - & - \\
\hline
\end{tabular}

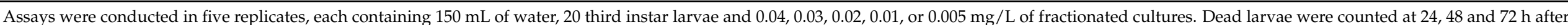

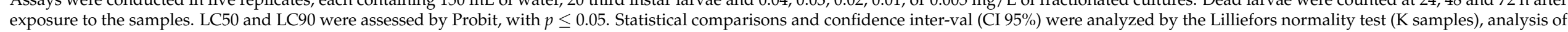

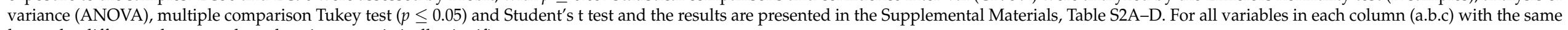
letter, the difference between the values is not statistically significant. 
SUP fractions had distinct levels of larvicidal activities, varying from Bacillus sp. strains SBC13 and GD02.13 with no activity at all up to $93 \%$ of mortality of A. aegypti larvae within $72 \mathrm{~h}$ in the presence of B. safensis SX15 SUP (Figure 2A). LCs determined for SUP fractions of SX15 and Spa07 were statistically indistinguishable from LCs determined for the positive control B. thuringiensis BR101 SUP (i.e., $72 \mathrm{~h} \mathrm{LC} 900.004 \mathrm{mg} / \mathrm{mL}$, Table 3 and Table S2A).

The mixture of SUP and APEL fractions were also tested. Noticeable results were obtained for the Bacillus sp. SP06 and B. safensis SPa22 strains. While these strains demonstrated very low larvicidal activities when SUP and APEL were tested separately, the mixture of the two fractions resulted in 100\% mortality within $24 \mathrm{~h}$ for SP06 and $72 \mathrm{~h}$ for $B$. safensis SPa22. For B. safensis SPa22, a strain for which no larvicidal activity was detected in the SUP fraction, the APEL+SUP yielded $\mathrm{LC}_{50}$ and $\mathrm{LC}_{90}$ values lower than APEL only (Table 3). Furthermore, assays with B. safensis SPa22 APEL+SUP resulted in earlier lethality, $65 \%$ mortality at $24 \mathrm{~h}$ and $100 \%$ at $72 \mathrm{~h}$ (Figure $2 \mathrm{D})$.

\section{Discussion}

The control of $A$. aegypti mosquitoes, vectors of diseases such as dengue, yellow fever, Zika and chikungunya, is an effective way for containing pathogen transmission to humans. However, current evidence suggests that the development of insecticide resistance is constantly challenging our ability to introduce new chemical and biological insecticides. For example, two years ago clothianidin, representing a new class of chemicals, was added by the World Health Organization to the list of insecticides indicated for indoor mosquito control. The recent report of mosquito resistance to clothianidin coming from Cameroon indicates its effectiveness for the proposed public health application may be already compromised [37].

Aiming to explore the biodiversity of the Amazon rainforest [25] and to identify novel entomopathogenic bacterial strains with larvicidal activity against $A$. aegypti, water and soil samples from 15 locations in the Amazonas state were collected and analyzed. Nonsporulated microbes were selectively eliminated by heat treatment and the surviving strains were isolated on Petri dishes containing nutritionally rich medium and agar. Seventyseven isolated bacterial strains assembled a collection containing representatives of six genera: Bacillus, Brevibacillus, Achromobacter, Serratia, Klebsiella and Brevundimonas (Table S1). Among them, 19 Bacillus sp. strains and two Brevibacillus halotolerans strains had larvicidal activity defined as the killing of at least $50 \%$ of the larvae within $72 \mathrm{~h}$.

For the first time, strains of Brevibacillus halotolerans with larvicidal activity against A. aegypti were identified. Other bacteria of the genus Brevibacillus, such as Brevibacillus laterosporus have been characterized as having insecticidal activities against insects [38]. $\mathrm{Br}$. laterosporus canoe-shaped spores (CSPB) contain four major proteins, $\mathrm{CpBA}, \mathrm{CpbB}, \mathrm{CHRD}$ and ExsC, that function as insect virulence factors [39]. Further studies are necessary to verify if the insecticidal activities from the Br. halotolerans strains isolated in this study are associated with similar proteins.

Bacillus thuringiensis produces, during sporulation, cellular proteinaceous crystalline toxins (Cry and Cyt proteins or d-endotoxins) with insecticidal activity against certain insect species. Additionally, vegetative $B$. thuringiensis cells secrete into the environment Vip (vegetative insecticidal proteins) and Sip (secreted insecticidal proteins), which also have insecticidal activity [40]. Commonly, the cytotoxic effect and host specificity of B. thuringiensis, are attributed to cellular components (Cry and Cyt) or the secreted proteins of the Vip and Sip families. However, numerous other virulence factors of $B$. thuringiensis have been discovered, including lipopeptides (surfactin, iturin, fengicin), metalloproteases, chitinases, aminopolyol antibiotics and nucleotide-mimicking moieties. These agents contribute to the insecticidal properties of $B$. thuringiensis enhancing toxin activity, avoiding host immune response evasion and participating in extracellular matrix degeneration [41,42]. Additional studies are necessary to verify if the insecticidal activities from the Bacillus sp. strains isolated in this study are associated with similar proteins. 
Dahmana et al. [18], with the goal of evidencing and identifying multiple insecticidal components of 14 entomopathogenic bacteria against $A$. albopictus larvae, tested bacteriafree supernatant and disrupted bacterial pellet separately. Following a similar protocol, we exposed $A$. aegypti larvae to fractionated bacterial cultures; intact viable cells, autoclaved unviable cells, and bacterial culture medium depleted of cells. Larvicidal activities present in the culture medium and supernatant represent secreted molecules while cellular components are represented in the pellets. Eight out of the 21 tested strains contained one or more fractions resulting in at least 50\% mortality when fractionated cultures were assayed at a concentration of $5 \mathrm{mg} / \mathrm{mL}$. The PEL fractions of all eight strains submitted to fractionation resulted in mortality of at least $50 \%$ within $72 \mathrm{~h}$, five of them killing $100 \%$ of the $A$. aegypti larvae in less than $24 \mathrm{~h} . \mathrm{LC}_{50}$ and $\mathrm{LC}_{90}$ determined for these strains are similar to those of the reference $B$. thuringiensis strain BR101, suggesting they could be developed commercially as A. aegypti control agents. Autoclaved pellets lost most of their larvicidal activity, likely due to denaturation of the active components and/or the destruction of mechanisms requiring cell metabolism and replication. Notably, the autoclaved pellet from B. safensis SPa22 demonstrated consistently a delayed effect, killing A. aegypti larvae only after $48 \mathrm{~h}$ of exposure (Figure 2C). The mechanism involved in this late action deserves investigation.

Mortality of $A$. aegypti larvae was detected after exposure to SUP fractions of four strains, indicative that these bacteria secrete molecules with larvicidal activities. Possibly, $B$. safensis found in our study is similar to that described by [43], with culture supernatant effective against $A$. aegypti. Further investigation is necessary to uncover their molecular composition and how these agents contribute to the observed insecticidal properties.

We also tested mixing APEL and SUP fractions to evaluate the possibility of synergistic interactions between secreted compounds and cellular constituents. Synergism between $B$. thuringiensis cellular and secreted factors of selected strains have already been described $[42,44]$. The mixture APEL+SUP from Bacillus sp. SP06 and B. safensis SPa22 strains resulted in larvicidal activity superior to the sum of those of each fraction separately indicative of synergism between the components of APEL and SUP fractions.

\section{Conclusions}

We isolated Amazonian bacterial strains that exhibit larvicidal activity comparable to a commercial bacterial insecticide product (Bti) against $A$. aegypti. The data are promising for potentially developing novel bioinsecticides for the control of mosquitoes of medical importance. Larvicidal activities of their separated supernatant and pellet fractions were investigated and studies are needed to characterize their insecticidal compounds and mechanisms of action.

Supplementary Materials: The following are available online at https:/ / www.mdpi.com/article/10 .3390 / tropicalmed6020104/s1, Table S1: Bacillus strains isolated from soil and water samples from the municipalities of Parintins, Manaus and Coari, Amazonas state, Brazil, Table S2A-D: LC 50 and $\mathrm{LC}_{90}$ values of microbial cultures larvicidal activity against Aedes aegypti larvae.

Author Contributions: Conceptualization, R.M.K., A.Q.L.d.S. and W.P.T.; methodology, R.M.K., E.M.R., V.A.M., J.C.O. and M.R.O.; software, R.M.K., W.R.S. and R.A.R.; validation, R.M.K., E.M.R., A.Q.L.d.S. and W.P.T.; formal analysis, R.M.K., E.M.R., W.R.S., R.A.R. and O.M.; investigation, R.M.K. and E.M.R.; resources, A.Q.L.d.S., W.P.T. and O.T.; data curation, R.M.K., E.M.R. and O.M.; writingoriginal draft preparation, R.M.K., E.M.R. and F.A.S.F.; writing-review and editing, R.M.K., E.M.R., O.T., J.A.S.-N. and O.M.; supervision, R.M.K., E.M.R., O.T., J.A.S.-N. and O.M. All authors have read and agreed to the published version of the manuscript.

Funding: This study was financed in part by the Coordenação de Aperfeiçoamento de Pessoal de Nível Superior-Brasil-CAPES—(Grant ID 001), by the Pró-Amazônia: Biodiversidade e Sustentabilidade (Grant ID 23038.009442/2013-12) and by a project of the Swedish Research Council (Grant ID 384-2012-622). 
Institutional Review Board Statement: All biological material collected and analyzed during the present study was collected with official authorization (21263-1) from the 'Biodiversity Authorization and Information System' (SISBIO) of the Ministry of the Environment (MMA). Animal experiments were approved by the Animal Use Ethics Committee (CEUA: 053/2018 SEI 01280.001770/2018-71). All experiments were conducted in accordance with relevant guidelines and regulations and in compliance with ARRIVE guidelines.

Informed Consent Statement: Not applicable.

Data Availability Statement: All data generated or analyzed during this study are included in this published article and its Supplementary Information Files. DNA sequences are available in the database GenBank at National Center for Biotechnology Information www.ncbi.nlm.nih.gov accessed on 14 June 2021, with access numbers MT052595-MT052669 and MT163315-MT163316.

Acknowledgments: We thank the Graduate Program in Biotechnology-PPGBIOTEC/ UFAM and the National Institute for Research in the Amazon-INPA. We thank João Cirino Zequi, Gislene Vilas Boas and Joelma Soares da Silva. Jayme A. Souza-Neto was a São Paulo Research Foundation (FAPESP) Young Investigator (Grant Number 2013/11343-6).

Conflicts of Interest: The authors declare no conflict of interest.

\section{References}

1. Ferreira-De-Brito, A.; Ribeiro, I.P.; De Miranda, R.M.; Fernandes, R.S.; Campos, S.S.; Da Silva, K.A.B.; De Castro, M.G.; Bonaldo, M.C.; Brasil, P.; Lourenço-De-Oliveira, R. First detection of natural infection of Aedes aegypti with Zika virus in Brazil and throughout South America. Memórias Inst. Oswaldo Cruz 2016, 111, 655-658. [CrossRef]

2. Aragão, C.F.; Cruz, A.C.R.; Neto, J.P.N.; Monteiro, H.A.D.O.; Da Silva, E.V.P.; Da Silva, S.P.; Andrade, A.T.D.S.; Tadei, W.P.; Pinheiro, V.C.S. Circulation of Chikungunya virus in Aedes aegypti in Maranhão, Northeast Brazil. Acta Trop. 2018, 186, 1-4. [CrossRef]

3. Souza-Neto, J.A.; Powell, J.R.; Bonizzoni, M. Aedes aegypti vector competence studies: A review. Infect. Genet. Evol. 2019, 67, 191-209. [CrossRef] [PubMed]

4. Kilpatrick, A.M.; Randolph, S.E. Drivers, dynamics, and control of emerging vector-borne zoonotic diseases. Lancet 2012, 380, 1946-1955. [CrossRef]

5. Nóbrega, M.; Araújo, E.L.D.L.; Wada, M.Y.; Leite, P.L.E.; Dimech, G.S.; Percio, J. Surto de síndrome de Guillain-Barré possivelmente relacionado à infecção prévia pelo vírus Zika, Região Metropolitana do Recife, Pernambuco, Brasil, 2015. Epidemiol. Serv. Saude Rev. Sist. Unico Saude Bras. 2018, 27, e2017039. [CrossRef]

6. Paixão, E.S.; Teixeira, M.G.; Rodrigues, L.C. Zika, chikungunya and dengue: The causes and threats of new and re-emerging arboviral diseases. BMJ Glob. Health 2018, 3, e000530. [CrossRef]

7. Cattarino, L.; Rodriguez-Barraquer, I.; Imai, N.; Cummings, D.A.T.; Ferguson, N.M. Mapping global variation in dengue transmission intensity. Sci. Transl. Med. 2020, 12, eaax4144. [CrossRef] [PubMed]

8. Heukelbach, J.; Alencar, C.H.; Kelvin, A.A.; De Oliveira, W.K.; Cavalcanti, L. Zika virus outbreak in Brazil. J. Infect. Dev. Ctries. 2016, 10, 116-120. [CrossRef] [PubMed]

9. Stawicki, S.P.; Sikka, V.; Chattu, V.K.; Popli, R.K.; Galwankar, S.C.; Kelkar, D.; Sawicki, S.G.; Papadimos, T. The emergence of zika virus as a global health security threat: A review and a consensus statement of the INDUSEM Joint working Group (JWG). J. Glob. Infect. Dis. 2016, 8, 3-15. [CrossRef]

10. Jones, R.; Kulkarni, M.A.; Davidson, T.M.V.; Talbot, B. RADAM-LAC Research Team Arbovirus vectors of epidemiological concern in the Americas: A scoping review of entomological studies on Zika, dengue and chikungunya virus vectors. PLoS ONE 2020, 15, e0220753. [CrossRef]

11. Wilson, A.L.; Courtenay, O.; Kelly-Hope, L.A.; Scott, T.W.; Takken, W.; Torr, S.; Lindsay, S.W. The importance of vector control for the control and elimination of vector-borne diseases. PLoS Negl. Trop. Dis. 2020, 14, e0007831. [CrossRef] [PubMed]

12. Moyes, C.L.; Vontas, J.; Martins, A.; Ng, L.C.; Koou, S.Y.; Dusfour, I.; Raghavendra, K.; Pinto, J.; Corbel, V.; David, J.-P.; et al. Contemporary status of insecticide resistance in the major Aedes vectors of arboviruses infecting humans. PLoS Negl. Trop. Dis. 2017, 11, e0005625. [CrossRef]

13. Weetman, D.; Kamgang, B.; Badolo, A.; Moyes, C.L.; Shearer, F.M.; Coulibaly, M.; Pinto, J.; Lambrechts, L.; McCall, P.J. Aedes mosquitoes and Aedes-borne arboviruses in Africa: Current and future threats. Int. J. Environ. Res. Public Health 2018, 15, 220. [CrossRef]

14. Lereclus, D.; Agaisse, H.; Grandvalet, C.; Salamitou, S.; Gominet, M. Regulation of toxin and virulence gene transcription in Bacillus thuringiensis. Int. J. Med. Microbiol. 2000, 290, 295-299. [CrossRef]

15. Iturbe-Ormaetxe, I.; Walker, T.; Neill, S.L.O. Wolbachia and the biological control of mosquito-borne disease. EMBO Rep. 2011, 12, 508-518. [CrossRef] [PubMed]

16. Lazarte, J.N.; Lopez, R.P.; Ghiringhelli, P.D.; Berón, C.M. Bacillus wiedmannii biovar thuringiensis: A specialized mosquitocidal pathogen with plasmids from diverse origins. Genome Biol. Evol. 2018, 10, 2823-2833. [CrossRef] 
17. Evans, H.C.; Elliot, S.L.; Barreto, R.W. Entomopathogenic fungi and their potential for the management of Aedes aegypti (Diptera: Culicidae) in the Americas. Memórias Inst. Oswaldo Cruz 2018, 113, 206-214. [CrossRef] [PubMed]

18. Dahmana, H.; Raoult, D.; Fenollar, F.; Mediannikov, O. Insecticidal activity of bacteria from larvae breeding site with Natural Larvae Mortality: Screening of Separated Supernatant and Pellet Fractions. Pathogens 2020, 9, 486. [CrossRef] [PubMed]

19. Arantes, O.M.N.; Vilas Bôas, L.A.; Vilas Bôas, G.T.T. Bacillus thuringiensis: Estratégias no controle biológico. In Biotecnologia: Avanços na Agricultura e na Agroindústria; Coleção Biotecnologia; Agropecuária: Caxias do Sul, Brazil, 2002; pp. 269-293. ISBN 85-7061-188-9.

20. Galardo, A.K.R.; Zimmerman, R.; Galardo, C.D. Larval control of Anopheles (Nyssorhinchus) darlingi using granular formulation of Bacillus sphaericus in abandoned gold-miners excavation pools in the Brazilian Amazon Rainforest. Rev. Soc. Bras. Med. Trop. 2013, 46, 172-177. [CrossRef] [PubMed]

21. Ferreira, F.A.D.S.; Arcos, A.N.; Sampaio, R.T.D.M.; Rodrigues, I.B.; Tadei, W.P. Effect of Bacillus sphaericus Neide on Anopheles (Diptera: Culicidae) and associated insect fauna in fish ponds in the Amazon. Rev. Bras. Ėntomol. 2015, 59, 234-239. [CrossRef]

22. Short, S.M.; Van Tol, S.; MacLeod, H.J.; Dimopoulos, G. Hydrogen cyanide produced by the soil bacterium Chromobacterium sp. Panama contributes to mortality in Anopheles gambiae mosquito larvae. Sci. Rep. 2018, 8, 1-13. [CrossRef] [PubMed]

23. Da Silva, J.L.R.; Schwalm, F.U.; Silva, C.E.; Da Costa, M.; Heermann, R.; Da Silva, O.S. Larvicidal and Growth-Inhibitory Activity of Entomopathogenic Bacteria Culture Fluids Against Aedes aegypti (Diptera: Culicidae). J. Econ. Èntomol. 2017, 110, 378-385. [CrossRef]

24. Lovett, B.; Bilgo, E.; Diabate, A.; Leger, R.S. A review of progress toward field application of transgenic mosquitocidal entomopathogenic fungi. Pest Manag. Sci. 2019, 75, 2316-2324. [CrossRef]

25. Malhi, Y.; Roberts, J.T.; Betts, R.A.; Killeen, T.J.; Li, W.; Nobre, C.A. Climate Change, Deforestation, and the Fate of the Amazon. Science 2008, 319, 169-172. [CrossRef]

26. World Health Organization. Informal Consultation on the Development of Bacillus sphaericus as Microbial Larvicide; WHO: Geneva, Switzerland, 1985; 24p.

27. Polanczyk, R.A. Estudos de Bacillus thuringiensis Berliner Visando ao Controle de Spodoptera frugiperda; Universidade de Sao Paulo: Sao Paulo, Brazil, 2004.

28. Fukatsu, T.; Nikoh, N. Two Intracellular Symbiotic Bacteria from the Mulberry Psyllid Anomoneura mori (Insecta, Homoptera). Appl. Environ. Microbiol. 1998, 64, 3599-3606. [CrossRef]

29. Sawada, H.; Ieki, H.; Oyaizu, H.; Matsumoto, S. Proposal for Rejection of Agrobacterium tumefaciens and Revised Descriptions for the genus Agrobacterium and for Agrobacterium radiobacter and Agrobacterium rhizogenes. Int. J. Syst. Bacteriol. 1993, 43, 694-702. [CrossRef] [PubMed]

30. Terenius, O.; De Oliveira, C.D.; Pinheiro, W.D.; Tadei, W.P.; James, A.A.; Marinotti, O. 16S rRNA gene sequences from bacteria associated with adult Anopheles darlingi (Diptera: Culicidae) mosquitoes. J. Med. Èntomol. 2008, 45, 172-175. [CrossRef]

31. Huang, X. CAP3: A DNA Sequence Assembly Program. Genome Res. 1999, 9, 868-877. [CrossRef]

32. WHO. Guidelines for Laboratory and Field Testing of Mosquito Larvicides; WHO: Geneva, Switzerland, 2005.

33. Soares-Da-Silva, J.; Queirós, S.G.; De Aguiar, J.S.; Viana, J.L.; Neta, M.D.R.; Silva, M.; Pinheiro, V.C.; Polanczyk, R.A.; CarvalhoZilse, G.A.; Tadei, W.P. Molecular characterization of the gene profile of Bacillus thuringiensis Berliner isolated from Brazilian ecosystems and showing pathogenic activity against mosquito larvae of medical importance. Acta Trop. 2017, 176, 197-205. [CrossRef]

34. Finney, D.J. Probit Analysis. J. Pharm. Sci. 1971, 60, 1432. [CrossRef]

35. Robertson, J.L.; Savin, N.E.; Preisler, H.K. Bioassays with Arthropods; CRC Press: Boca Raton, FL, USA, 2007.

36. Ayres, M.; Ayres, M., Jr.; Ayres, D.L.; Santos, A.A. BioEstat Versão 5.3: Aplicações Estatísticas Nas Áreas Das Ciências Biológicas e Médicas; Sociedade Civil Mamirauá: Belém, Pará, Brasil; MCT/CNPQ: Brasília, Brasil, 2007.

37. Makoni, M. Malaria fighters' latest chemical weapon may not last long. Science 2020, 369, 1153. [CrossRef] [PubMed]

38. Ruiu, L. Brevibacillus laterosporus, a Pathogen of Invertebrates and a Broad-Spectrum Antimicrobial Species. Insects 2013, 4, 476-492. [CrossRef] [PubMed]

39. Marche, M.G.; Mura, M.E.; Falchi, G.; Ruiu, L. Spore surface proteins of Brevibacillus laterosporus are involved in insect pathogenesis. Sci. Rep. 2017, 7, srep43805. [CrossRef]

40. Palma, L.; Muñoz, D.; Berry, C.; Murillo, J.; Caballero, P. Bacillus thuringiensis toxins: An Overview of Their Biocidal Activity. Toxins 2014, 6, 3296-3325. [CrossRef] [PubMed]

41. Chaabouni, I.; Guesmi, A.; Cherif, A. Secondary Metabolites of Bacillus: Potentials in Biotechnology; Springer Science and Business Media LLC: Berlin/Heidelberg, Germany, 2012; pp. 347-366.

42. Malovichko, Y.V.; Nizhnikov, A.A.; Antonets, K.S. Repertoire of the Bacillus thuringiensis Virulence Factors Unrelated to Major Classes of Protein Toxins and Its Role in Specificity of Host-Pathogen Interactions. Toxins 2019, 11, 347. [CrossRef]

43. Falqueto, S.A.; Pitaluga, B.F.; de Sousa, J.R.; Targanski, S.K.; Campos, M.G.; Mendes, T.A.D.O.; da Silva, G.F.; Silva, D.H.S.; Soares, M.A. Bacillus spp. metabolites are effective in eradicating Aedes aegypti (Diptera: Culicidae) larvae with low toxicity to non-target species. J. Invertebr. Pathol. 2021, 179, 107525. [CrossRef] [PubMed]

44. Valtierra-De-Luis, D.; Villanueva, M.; Lai, L.; Williams, T.; Caballero, P. Potential of Cry10Aa and Cyt2Ba, two minority $\delta$ endotoxins produced by Bacillus thuringiensis ser. israelensis, for the control of Aedes aegypti larvae. Toxins 2020, $12,355$. [CrossRef] 